\title{
Texas School District Hiring Managers Perceive Academic Accomplishments of PK-12 Campus Administrator Applicants in Relation to the Applicant's Institution's Reputation.
}

\author{
Sandy Cortez-Rucker and Vance Cortez-Rucker
}

\begin{abstract}
This study was designed to test if educational leadership degree earned through an online program was related to Human Resource (HR) Directors' hiring decisions of administrators in Texas public school. The research questionaddressed in this study was: What is the relationship of an institution's reputation to Texas school district hiring managers' perception of academic accomplishments of PK-12 campus administrator applicants?The research design was a cross sectional survey that was a revised replication of Adams, Lee, and Cortese (2012). The sample is a stratified sampling of Human Recourse (HR) Directors or designee for hiring administrators for the school district by Regional Educational Service Centers (ESC). Despite the increasing number and quality of online degrees, many employers are still not willing to hire applicants who earned a degree online (Adams, 2008; Adams \& DeFleur, 2005; Bailey \& Flegie, 2012; Columbaro \& Monaghan, 2009; Glover, 2005; Guendoo, 2007, 2008; Udegbe, 2012; Zupek, 2010).

This study will provide information to assist individuals within the area of higher education to gain a perspective of how their online programs will be received in the job market by their graduates. In addition, this study allows individuals, to look at data to assist in making degree or certification choices. Furthermore, this study will allow individuals to have a better perspective of how to respond to prospective employers, by knowing the opinions of Human Resource Directors.
\end{abstract}

\section{RESEARCH DESIGN}

The cross sectional survey research design was a replication study of Adams, Lee, and Cortese (2012), with the exception that this study investigated perceptions regarding the hiring of Pk-12 administrators instead of teachers. Additionally, this was a regional study (Texas) instead of a national study. According to Creswell (2012), cross sectional survey research design is used to discover an individual's opinion, ascertain essential beliefs, and determine attitudes as well as community needs. Babbie (2010) suggested that survey research was one of the best ways for a researcher to collect original data when a population is too large and in too vast of a geographic expanse to observe directly.

\section{SAMPLE}

Stratified sampling was used to select a representative sample from the total population of Texas school districts $(N=1,012)$ to participate in the study. The sample was stratified by educational service center (ESC) region, of which there are 20 within the state of Texas. ESC centers are regionally located throughout the state of Texas and act as a liaison between the individual school districts and the Texas Education Administration (TEA), which is the headquarters for the state of Texas. The ESCs provide support to school districts through workshops and technical assistance of directives by TEA. ESCs also provide school districts with information in an advisory capacity. The actual number of participants who responded to the survey was 115 with a $41.37 \%$ response rate of the cross-sectional stratified sampling from the total population of Texas public school. Since this was a blind study, knowing the identity of the school district and location of the participants was impossible. We do know the participants were primarily from rural school districts of Texas by their response to the setting of their school district.

Using Ocher's (2007) sample size formula to maintain proportional representativeness in the stratification process, respondents from 278 districts were found to be an appropriate sample size with a $95 \%$ confidence interval and a 5\% margin of error. Ocher's formula is as follows:

$$
\frac{\text { NumberofdistrictsinESCRegion }}{\text { TotalnumberofdistrictsinTexas }}=\frac{x \text { (NumberofdistrictsperRegion })}{\text { Numberofdistrictsinsample }}
$$

For the purpose of this study, the respondents were serving as either an HR Director or the designee for hiring administrators within the selected school districts. Table 1 shows the number of schools and required sample size identified for each regional service center needed, based upon Ocher's (2007) formula. 


\section{DATA COLLECTION PROCEDURES}

The survey was administered via the Internet usingSurveyMonkey and participants were provided an electronic link to the survey in the initial contact email. Respondents were given the option of exiting the survey or participate. All questions were set up to require a response. Respondents were given the option to make comments on selected questions throughout the survey and were able to make any follow-up comments on the final page of the survey. To increase response rates, a follow-up email letter was sent after one week of the survey being available (Dillman, 2007, 2014).

\section{DATA ANALYSIS}

The data were analyzed with descriptive and inferential statistics, extracting the raw data collected from an online survey collection program, where respondents completed the survey questions. Frequencies and percentages were used to describe the sample. Means, standard deviations, and content analysis of comment sections throughout the survey. Chi-square analyses were used to test the relationship between applicant selection and the respondents' demographic traits and their background information as were completed in original survey (Adams et al., 2012). The survey instrument contained both close-ended and open-ended questions. Since the focus of this study was to look at opinions, beliefs, and attitudes, it was important to allow the respondents to maintain anonymity, which the survey questionnaire allowed (Patten, 2001).

Research question.TheResearch question asked, "What is the relationship of an institution's reputation to Texas school district hiring managers' perception of academic accomplishments of $\mathrm{P}-12$ campus administrator applicants?" The reputation of an institute of hiring education was a noteworthy area of contention. Most of the information for this question was drawn from the open-ended portions of question responses. Reputation should be questioned more fully if this type of study were examined for further research.

One question did speak to the area of reputation, which asked if respondents considered online coursework from for-profit institutions equivalent to traditional coursework. Respondents corroborated their opinion with almost a $64 \%$ reply of no. In addition to looking at this question in isolation, it was also compared to the two hypothetical hiring situations for a school administrator. To answer this question, descriptive statistics were used to compare the response options for two different hypothetical hiring scenarios by the sample of participants and their responses to their opinion of an institution's reputation. Hiring Situation One with two candidate possibilities, Applicant A (traditional face-to-face education) and Applicant B (fully online education); Hiring Situation Two with two candidate possibilities, Applicant A (traditional face-to-face) and Applicant B (hybrid). The results of these comparisons are shownin Table 1 and Table 2.

Table 1Results of Chi-Square and Descriptive Statistics for Institutional Reputation by Applicant for Hiring Situation One.

\begin{tabular}{lll}
\hline & \multicolumn{2}{c}{ Hiring Situation One } \\
\cline { 2 - 3 } Institution Reputation & Applicant A & Applicant B \\
Response & (Traditional) & (Fully Online) \\
\hline Yes & $\%(n)$ & $\%(n)$ \\
No & $24.34(28)$ & $12.17(14)$ \\
\hline
\end{tabular}

Note. $\chi^{2}=13.559, d f=1, p=.000$

Table 2Results of Chi-Square and Descriptive Statistics for Institution Reputation by Applicant for Hiring Situation Two.

\begin{tabular}{lll}
\hline & \multicolumn{2}{c}{ Hiring Situation Two } \\
\cline { 2 - 3 } Institution Reputation & Applicant A & Applicant B \\
Response & (Traditional) & (Hybrid) \\
& $\%(n)$ & $\%(n)$ \\
\hline Yes & $9.57(11)$ & $26.96(31)$ \\
No & $36.52(42)$ & $26.96(31)$ \\
\hline Note. $\chi^{2}=10.542, d f=1, p=.001$ & &
\end{tabular}

The survey question invited open-ended responses. There was a definite split between the respondents and their opinions for those who chose to respond to the open-ended comment section. The following comments were provided regarding reputation as it related to the survey question: "My preference would 
depend upon the reputation of the university. For instance, I would be more interested in hiring an individual with a Tier One university background than an individual with a degree from local college." Another comment from this question was, "The reputation of the said university would be important to me, but the method by which instruction was delivered would not be." One last comment on reputation was, "If the educational institution is not highly rated, then we would not be as interested in that applicant."

\section{CONCLUSIONS}

Based on this quantitative, cross-sectional stratified sampling survey, there were several conclusions about the increased number and quality of online degrees and the many employers still not willing to hire applicants who earned an online degree (Adams \& Defleur, 2005; Adams et al., 2012; Columbaro \& Monagham, 2009; Guedoo, 2007, 2008; Monaghan, 2009; Tharpe, 2014; Thompson, 2009; Udegbe, 2012; Zupek, 2010). The respondents to this study seemed to imply a preference to candidates with traditional coursework; however, the findings appeared to suggest that online learning, or, at least, hybrid coursework, has gained favor with a greater percentage than the Adams et al. (2012) study revealed. Nonetheless, online education coursework and degrees are far from widely accepted within the field of public, not for profit education.

\section{REFERENCES}

[1] Adams, J. (2008). Understanding the factors limiting the acceptability of online courses and degrees. International Journal on E-Learning, 7(4), 573-587. Retrieved from http:pilotmedia. com/adams/xPDF/improve_online degrees. Pdf

[2] Adams, J. (2016). Teaching certificates earned online and hiring practices of high school principals. Journal of Educational Issues, 2(1), 73-90. Retrieved from http://www.macrothink.org/journal/index.php/jei/article/view/8203/7338

[3] Adams, J., \&DeFleur, M. H. (2005). The acceptability of a doctoral degree earned online as a credential for obtaining a faculty position. The American Journal of Distance Education, 19(2), 71-85.

[4] Adams, J., \& DeFleur, M. H. (2006). The acceptability of online degrees earned as a credential for obtaining employment. Communication Education, 55(1), 32-45.

[5] Adams, J., DeFleur, M., Heald, G. (2007). The acceptability of online degrees in health hiring professions. Communication Education, 56(3), 292-307.

[6] Adams, J., Lee, S., \& Cortese, J. (2012). The acceptability of online degrees: Principals and hiring practices in secondary schools. Contemporary Issues in Technology and Teacher Education, 12(4), 408422. Retrieved from http://www. editlib. org/p/38477/

[7] Babbie, E. R. (2010). The practice of social research $\left(12^{\text {th }}\right.$ ed.). Belmont, CA: Wadsworth, Cengage Learning.

[8] Bailey, J. S., \&Flegie, L. V. (2012). Hiring managers' perceptions of the value of an online MBA. Online Journal of Distance Learning Administration, 15(11). Retrieved from http://www. westga.edu/distance/ojdla/summer152/bailey_flegle152. html

[9] Columbaro, N. L., \& Monaghan, C. H. (2009). Employer perceptions of online degrees: A. literature review.Journal of Distance Learning Administration, 12(1). Retrieved from http://www. westga.edu/ distance/ojdla/spring121/columbaro121.html

[10] Creswell, J. W. (2012). Educational research: Planning, conducting, and evaluating quantitative and qualitative research(4th ed.). Upper Saddle River, NJ: Pearson Education, Inc.

[11] DeFleur, M. H., Adams, J. (2004). Acceptability of online degrees as criteria for admission to graduate programs. Journal of Computing in Higher Education16(1), 150-163. Retrieved from http://pilotmedia.com/pmi/sites/all/xpdf/dl_grad.pdf

[12] Dillman, D. A., Smyth, J. D., \& Christian, L. M. (2007). Internet, mail, and mixed-mode surveys: The tailored design method(3rd ed.). Hoboken, NJ: John Wiley \& Sons, Inc.

[13] Dillman, D. A., Smyth, J. D., \& Christian, L. M. (2014). Internet, phone, mail, and mixed-mode surveys: The tailored design method (4th ed.).Hoboken, NJ: John Wiley \& Sons, Inc.

[14] Glover, K. (2005). Nextgen: don't discredit my online degree. Library Journal. Retrieved from http://www. libraryjournal/article/CA6269436. Html

[15] Guendoo, L. (2007). Credibility challenges to online doctoral graduates seeking faculty positions: A community college perspective. (Doctoral dissertation). Available from ProQuest Dissertations and Theses database. (UMI No. 3284074). Retrieved from http://search.proquest.com.libproxy.lamar.edu/dissertations/docview/304720558/B55BBDE7128F467CP $\mathrm{Q} / 1$ ?accountid=7043 
[16] Guendoo, L. (2008). Community colleges friendlier to online PhDs. Online Journal of Distance Learning Administration,11(3). Retrieved from http://distance.westga.edu/ distance/ojdla/fall113/guendoo113. html

[17] Ocher, L. T. (2007). Conducting a survey: Techniques for a term project. Glendale, CA: Pyrczak Publishing.

[18] Patten, M. L. (2001). Questionnaire research: A practical guide (2nd ed.). Los Angeles: Pyrczak Publishing.

[19] Tharpe, A. A. (2014). University administrators' perception of online and blended doctoral degrees (Doctoral Dissertation, Liberty University). Retrieved from http://digitalcommons.liberty.edu/cgi/viewcontent.cgi?article=1964\&context=doctoral

[20] Thompson, L. D. (2009). Perceptions of employers toward hiring graduates with online degrees (Doctoral Dissertation). Retrieved from http://digitalscholarship.univ.edu/thesesdissertations

[21] Udegbe, I. B. (2012). Attitudes of prospective human resource personnel towards distance learning degrees. Online Journal of Distance Learning Administration, 15(1). Retrieved from http://www.westga.edu/ $\sim_{\text {distanceojdla }} /$ spring151/udegbe.pdf

[22] Zupek, R. (2010, March 29). Employers on online education [Web log post]. Retrieved from http://www.cnn.2010/LIVING/worklife/03/29/cb.employers.online/index. html 